\title{
Consideration and the Law of Trusts
}

The law is generally settled, both in this country and in England, that where a trust has been completely declared, the absence of consideration is immaterial so far as both the trustor, or settlor, and the trustees are concerned. ${ }^{1}$

An interesting question as to whether or not the law is the same in this state is presented by certain of our code sections.

Section 2221 of our Civil Code provides that

"Subject to the provisions of section eight hundred and fiftytwo, a voluntary trust is created, as to the trustor and beneficiary, by any words or acts of the trustor, indicating with reasonable certainty :

1. An intention on the part of the trustor to create a trust; and,

2. The subject, purpose, and beneficiary of the trust."

Section 2222 of the Civil Code provides that

"Subject to the provisions of section eight hundred and fiftytwo, a voluntary trust is created, as to the trustee, by any words or acts of his indicating, with reasonable certainty:

1. His acceptance of the trust, or his acknowledgment, made upon sufficient consideration, of its existence; and,

2. The subject, purpose, and beneficiary of the trust."

That it was the intention of those who drafted the code to make a distinction under certain circumstances in the matter of consideration, as between the settlor or trustor on the one hand and the trustee on the other hand is obvious, not only from the difference in the language of the two sections, but also from the citation by the Code Commissioners of the New York case of Day v. Roth. ${ }^{2}$

In that case the court said:

"A person in the legal possession of money or property, acknowledging a trust, becomes from that time a trustee, if the acknowledgment is founded on a valuable or meritorious consideration. His antecedent relation to the subject, whatever it may have been, no longer controls, and therefore it is not the material fact to be ascertained." 3

The statement would, however, appear to be but dictum. A consideration seems to have existed under the facts of the case,

139 Cyc. 42 ; Bogert on Trusts, p. 65 ; Perry on Trusts (6th ed.) $\S 96$.

2 (1858) $18 \mathrm{~N}$. Y. 448.

318 N. Y. 448,453 . (Italics added.) 
although of a somewhat attenuated character. It is to be found in the execution by the beneficiary at the request of the alleged trustee of a power of attorney, authorizing him to take charge of and invest a sum which the beneficiary had theretofore entrusted to the trustee for that purpose under an oral authorization. However, no weight seems to have been given by the court to this fact as indicating the presence of consideration.

The court in support of the statement quoted above cites several English cases apparently as authorities for the rule there laid down. None of those cases, however, can properly be regarded as laying down any such rule.

The leading case of Ex parte $\mathrm{Pye}^{4}$ which is cited, was at one time apparently believed by one authority to involve a "meritorious consideration." The case is now, however, generally regarded as the first case clearly holding that a trust fully declared need not be supported by a consideration in order to be enforceable.

Although the language in Day v. Roth $^{6}$ as to the necessity for a consideration appears never to have been expressly modified, the New York doctrine today seems to be in accord with the general rule in not requiring a consideration in order to render a fully declared trust enforceable, even as against the trustee.

The distinction made in our code between the validity of a trust so far as the trustor on the one hand or the trustee on the other hand is concerned, has not been emphasized in our decisions. The rule has commonly been stated in general terms that the presence or absence of a consideration is not a material matter.

A brief review of the different classes of cases in which the question has been involved is essential as a preliminary to a consideration of the effect to be given to our code sections on this subject.

Let us take the simple case of the creation of a trust in favor of a third person as a beneficiary. In the case of Kopp v. Gunther, ${ }^{8}$ the settlor attempted to secure a reconveyance to him of certain land which he had deeded to the defendant in trust, on the ground, among others, that he, the trustor, had received no consideration for the conveyance. The court refused him any relief holding that "the averment of want of consideration is immaterial." This case

1 (1811) 18 Ves. 140, 11 Eng. Rep. R. 173.

5 Adams on Equity, 68 Law Lib. star pp. 80, 98.

6 Supra, n. 2.

7 See Chaplin on Express Trusts and Powers, p. 56.

8 (1892) $95 \mathrm{Cal}$. 63, $30 \mathrm{Pac} .301$.

995 Cal. 63, 74. Also see National Bank v. Exchange Nat. Bank (1921) 186 Cal. 172, 180, 199 Pac. 1. 
is clearly in accord with the code since, under its terms (section 2221), no consideration is required so far as the trustor is concerned.

In the case of Nichols v. Emery, ${ }^{10}$ it appears that the settlor conveyed certain property to a trustee on certain trusts expressed in the deed in favor of the former's children. One of his heirs who was also one of the beneficiaries contested the validity of the trust, claiming, among their other grounds of contest, that there was no consideration for the trust. In passing on this contention, the court held that,

"The deed being a voluntary settlement for the settlor's children, and being fully executed, does not require other consideration for its support than that of parental affection and duty."11

Although the decision is correct, the language quoted is misleading, if not unsound. It is an application of the old doctrine that an executory trust would be upheld in favor of the wife or child of the settlor, on the ground that the relationship between the parties constitutes a good or meritorious consideration..$^{12}$ The weight of authority is today against the sufficiency of such consideration in the case of such an executory trust. ${ }^{13}$

However, as stated, the ultimate holding that a consideration was not necessary is correct since the code in effect provides that not only as to the trustor, but also as to the beneficiaries, a consideration is not essential to the validity of the trust.

In the case of Elizalde v. Elizalde, ${ }^{14}$ a legatee under the will of the testator was given a sum of money in trust. Upon delivery of the money to the trustee, he executed a written acknowledgment that he held the money in trust for the beneficiary. The court in upholding the trust quoted section 2222 of the Civil Code, which, it will be recalled, refers to the necessity for a consideration so far as a trustee is concerned, said,

"Here is a sufficient acknowledgment of the trust, with specific reference to the will of the mother, from which the terms of the trust can be ascertained."15

No comment was made by the court on the fact that no con-

10 (1895) 109 Cal. 323, 41 Pac. 1089, 50 Am. St. Rep. 43.

11 109 Cal. 323, 332.

12 Perry on Trusts (6th ed.) § 107.

13 Cf. Bogert on Trusts, p. 67 .

14 (1902) 137 Cal. 634, 66 Pac. 369, 70 Pac. 861.

15137 Cal. 634, 636. 
sideration had been received by the trustee. That fact, however, would not appear to be material in the case under any construction of the section, since the intent of the testator that the legatee should take the money subject to the duty of paying it over to the beneficiary had been plainly expressed. Hence, under the most elementary principles of equity, the legatee, having taken the money with knowledge of the expressed intent of the testator, took it charged with the trust.

Of course, a trustee is not bound to undertake the execution of the duties of the trust, but may disclaim, in which case another trustee will be appointed. ${ }^{16}$ But if he does not disclaim the trust, he will hold the trust res subject to the duty of carrying out the obligation imposed on him by the trust.

If in the Elizalde case the will had not expressed the trust and the legatee had not known of the legacy prior to the death of the testator, the situation would have been entirely different. ${ }^{17}$

There is another line of cases of the same general type illustrating the application of the principle here involved. The cases referred to are those in which a bank account has been opened or changed so as to provide that the amount on deposit shall be payable to the beneficiary. No consideration passes in such cases, but the trust is upheld where it appears that the intention of the depositor was to create a trust. ${ }^{18}$ It is worthy of comment that the bank in those cases, rather than the original depositor, is held to be the trustee. This view of the situation may be questioned. ${ }^{19}$

16 Smith v. Davis (1891) 90 Cal. 25, 27 Pac. 26, 25 Am. St. Rep. 92.

$17 \mathrm{Cf}$. infra.

18 Booth v. Oakland Bank, etc. (1898) 122 Cal. 19, 54 Pac. 370; Halsted v. Central Savings Bank (1918) 36 Cal. App. 500, 172 Pac. 613; Drinkhouse v. German S. and L. Society (1911) 17 Cal. App. 162, 118 Pac. 953.

19 When an account (assuming it to be an ordinary commercial account, or even a savings account in a bank having a capital stock; cf. City of Los Angeles v. State Loan and Trust Co. (1895) 109 Cal. 396, 42 Pac. 149) has been opened in the books of such a bank, the relation between the bank and the depositor is ordinarily that of debtor and creditor. Fidelity Savings Assn. v. Rodgers (1919) $180 \mathrm{Cal} .683,182 \mathrm{Pac}$. 426. Hence the title to the monies deposited is in the bank, and in the absence of a segregation, upon the change being made in the form of the deposit, it may well be claimed that the essential element of a trust res is lacking. Upon this line of reasoning, it has been held that the depositor is the trustee and that the trust res is the chose in action held by him against the bank. Cf. Ide v. Pierce (1882) 134 Mass. 250. It may be, however, that a segregation is no longer required in this state under the circumstances stated in order that a valid trust may exist. It was loug ago settled in California that wheu a valid trust has once been created, the mere fact that the trustee has subsequently commingled the monies of the trust fund with his other assets, does not prevent the beneficiary from enforcing the trust. Elizalde v. Elizalde, 137 Cal. 634, 641; Lathrop v. Bampton (1866) 31 Cal. 17. And the language of the court in Molera v. 
But, assuming the law to be that the bank is the trustee, the decisions that a consideration is not necessary may be upheld upon the theory set forth in commenting on the case of Elizalde v. Elizalde. ${ }^{20}$

Another situation that is of interest in the present discussion involves a declaration by the owner of property that he holds such property in trust for another. Ever since the decision of Ex parte Pye, ${ }^{21}$ it has been held, as stated above, that the absence of consideration does not permit the grantor successfully to dispute the existence of the trust. As held in Estate of M. S. Webb, ${ }^{22}$

"If the trust is perfectly created, so that the donor or settlor has nothing more to do, and the person seeking to enforce it has need of no further conveyances from the settler, and nothing is required of the Court but to give effect to the trust as an executed trust, it will be carried into effect, although it was without consideration, and the possession of the property was not changed."2s

It will be noted that this holding goes upon the assumption that the trust has been "perfectly created". It is submitted that this doctrine likewise may be reconciled with the code provisions. Section 2221 provides, it will be recalled, that no consideration is required so far as the trustor is concerned. Where the trustor is also the trustee, there would appear to be no reason for holding that although the trustor as such may not successfully contend that a consideration is essential, it may be demanded by him as trustee. It must be borne in mind that our courts will go a long ways to reconcile our code provisions with the general law on the same subject. ${ }^{24}$

A case in which it was suggested that a consideration must be present, so far as the alleged trustee is concerned, is Stephens v. Lemoore Canal Company. ${ }^{25}$ In that case, one McKenna, a director of a corporation, had bought in stock at a sale for a delinquent assessment. The corporation alleged that he had bought it under an oral

Cooper (1916) $173 \mathrm{Cal} .259,160 \mathrm{Pac}$. 231, is open to the possible construction that a segregation at the time of the creation of the trust is not essential if a trustee who declares the trust then has in his possession a sum larger than or at least equal to the amount of the trust fund.

${ }^{20}$ Supra, n. 14.

21 Supra, n. 4.

22 Estate of M. S. Webb (1875) 49 Cal. $541,545$.

23 Accord: Lynch v. Rooney (1896) 112 Cal. 279, 44 Pac. 565; Taber v. Bailey (1913) 22 Cal. App. 617, 135 Pac. 975 ; cf. Viau v. Viau (1922) 57 Cal. App. 66, 207 Pac. 39 .

24 Cf. Estate of Emart (1919) 175 Cal. 238, 165 Pac. 707, L. R. A. 1917 F 866 ; also see Cal. Civ. Code, $\$ 5$.

25 (1913) 22 Cal. App. 579. 135 Pac. 707. 
agreement made prior to the consummation of the sale, that he would purchase the stock and hold it in trust for the corporation. The personal representative of the director who had purchased the stock (the director himself having died before litigation ensued) denied that there was any agreement that he (McKenna) would hold the stock in trust. The trial court, in addition to finding that the agreement, if made by the corporation as alleged, was void as against public policy, also found that the agreement to hold in trust, if made, was made after the sale occurred and was without consideration. Judgment was entered in favor of the personal representative of the director, and this judgment was affirmed on appeal. The appellate court called attention to the fact that under the language of section 2222 of the Civil Code, an express trust may be created by his "acceptance of the trust or his acknowledgment made upon sufficient consideration of its existence", and referred to the fact that the alleged trustee had received no consideration; as one of the grounds upon which it based its judgment in his favor.

It is submitted that if McKenna, as owner of the stock, had in fact declared that he held it in trust for the company, no consideration would have been necessary to the existence of a valid trust. Such would be the holding in other states under the facts of the case, $^{28}$ and, as pointed out above, since he would have been both the trustor and the trustee, a consideration should not be required in this state.

What force then is to be given to the code requirement of consideration so far as regards the trustee? It will be recalled that the code provides that as to the trustee there must be an "acceptance" of the trust or an "acknowledgment" by him of its existence made upon sufficient consideration.

The two terms may properly be differentiated. An acceptance of a trust ex vi termini implies a promise to carry out the conditions subject to which the trust res is conveyed to the trustee. We find the same principle of construction in the law of contracts. An "acceptance" of an offer to contract implies "both assent and agreement." ${ }^{27}$ Thus, as provided in section 1589 of the Civil Code:

"A voluntary acceptance of the benefit of a transaction is equivalent to a consent to all the obligations arising from it, so far as the facts are known, or ought to be known, to the person accepting."

26 Perry on Trusts (6th ed.) $\$ 96$. 389.

27 State v. Board of Public Service (1909) 81 Ohio St. 218, 223, 90 N. E. 
Under this same principle, the bare receipt and retention of property by a person who at the time it is delivered to him knows that it is delivered as a trust fund, the purpose of the trust being then made known to him, would obligate him to carry out the trust. The surrender to the trustee of the property, which he retains with knowledge of the purpose for which it has been given to him, would constitute a "prejudice suffered" by the trustor such as would render the trustee's implied promise to carry out the trust, enforceable. ${ }^{28}$

In brief, we may say that when one acts or fails to act, declares himself, or fails to declare himself, under such circumstances that a court of equity can properly say that he has in effect accepted a trust, the absence of other consideration than is to be implied from the assignment or conveyance, plus the acceptance, becomes immaterial. Hence the code properly dispenses with the necessity for other consideration when there has been an "acceptance" of a trust.

A mere acknowledgment of the existence of a trust on the other hand does not necessarily imply a promise to carry out the obligations of the trust. We have an analogous situation in the case of an acknowledgment of a debt barred by the statute of limitations. Thus it has been held that "the mere admission of a legal liability is not sufficient" to revive a barred debt. ${ }^{29}$ The California Supreme Court has also held that a bare acknowledgment is insufficient to take a claim out of the statute. The acknowledgment to be binding must contain "some reference to a debt which either of itself or with the aid of permissible evidence of extrinsic facts in explanation, amounts to an admission that there is a debt existing to the creditor to whom the writing is sent, which the debtor is liable to pay and willing to pay." 30

In like manner, if the acknowledgment of a trust goes beyond a bare admission of the existence of the trust and contains what amounts in effect to a promise to carry out the duties of the trust, it may properly be construed to constitute an acceptance and as such be binding though not based on other consideration than is to be implied from the acceptance.

But when the existence of a trust is merely acknowledged and the alleged trustee at the time of such acknozeledgment had acquired the title to the property in question from the trustor without knowledge of the latter's intention that he should hold it in trust, it would

${ }^{28}$ Cal. Civ. Code, $\$ 1605$.

29 Pritchard v. Howell (1853) 1 Wis. 131, 138, 60 Am. Dec. 363.

30 Clunin v. First Fed. Trust Co. (1922) 189 Cal. 248, 254, 207 Pac. 1009. (Italics added.) 
appear that a consideration should be required to render his acknowledgment enforceable as against him. If, however, the words of the alleged trustee go beyond a mere acknowledgment of a then existing trust and amount to the creation of a trust de novo, under the doctrine of Ex parte $\mathrm{Pye}^{31}$ a consideration would not be necessary. This differentiation might require some nice distinctions as to the effect of the language used, but the distinction made by the code is itself a nice one.

Thus assume, for example, that $A$ by a simple assignment, vests title to certain personal property in $B$ as trustee for $C$, to whom alone $A$ at the time of the assigument states his intention of creating a trust. B, having received the property with no knowledge of A's intention that he should hold as trustee for $C$, would take it free from the trust. Never having accepted the trust, either expressly or impliedly, he could not be decreed to be a trustee upon that theory. He would not hold the property under a resulting trust for the grantor, both because the grantor was not intended to be the beneficiary, and, even if such were the intention, for the more important reason that the mere lack of consideration is no longer sufficient to raise a resulting trust. ${ }^{32}$

There would probably be no constructive trust because, although reprehensible, there would appear to be nothing sufficiently inequitable in the retention of the property by the grantee under the circumstances as to justify the intervention of a court of equity. It is true that under section 2224 of the Civil Code,

"One who gains a thing by ... mistake ... is unless he has some other and better right thereto, an involuntary trustee of the thing gained, for the benefit of the person who would otherwise have had it."

But the facts assumed would not appear to show a mistake within the meaning of the Code. ${ }^{33}$

If in the case put the grantee should after acquiring title to the property learn that it was A's intention that he should hold the property as trustee and should merely "acknowledge" the trust, it is submitted that he could not be held to that promise unless he received a consideration therefor. Since notice to the trustee is not necessary to the validity of a trust, ${ }^{34}$ the trust would exist from

${ }^{31}$ Supra, n. 4.

32 Brooks v. Union Trust Co. (1905) 146 Cal. 134, 79 Pac. 843; Tillaux v. Tillaux (1897) 115 Cal. 663,47 Pac. 691.

${ }_{88}$ Cf. Cal. Civ. Code, $\$ \S 1577,1578$.

34 Donaldson y. Donaldson (1876) L. R. 3 Ch. D. 743, 34 L. T. 900, 24 W. R. 1037, Kay 711; cf. Perry on Trusts (6th ed.) $\$ 105$. 
the time of the assignment. But it could not be enforced until the trustee rendered it enforceable by acknowledging its existence for a consideration.

The situation would be in a way analogous to that presented when an oral trust in land is created. The trustee is not bound by such a trust on account of the statute of frauds requiring trusts in land to be in writing. He may, however, recognize the trust and render it enforceable even after being declared bankrupt, by executing a sufficient memorandum, even over the objection of his creditors. ${ }^{\text {as }}$

A situation somewhat similar to that assumed above, of the trustee taking the property in controversy without knowledge of the alleged trust, has arisen in a number of cases involving bequests and devises. Thus in the leading case of Schultz's Appeal, ${ }^{30}$ it appears that the testator desired to leave his estate to charity. He was informed that if he should die within thirty days, such a disposition would be ineffectual, but that he might make an absolute bequest to some individual upon the confidence and belief that when the latter should be informed of the testator's wishes, he would carry them out. The plan was adopted and the estate willed to the bishop of the church to which the decedent belonged. The devisee did not learn of the plan until after the death of the testator. The Supreme Court of Pennsylvania held that there was no enforceable trust of any kind created and upheld the will. No express trust could be shown to have been intended by reason of the statute of wills, and r constructive trust decreed by reason of the absence of the essential eiement of fraud.

The same doctrine has been enunciated in this state..$^{37}$ The mere fact that after learning of the testator's intention the devisee should declare or even testify that he felt morally obligated to carry out the testator's desires, and that he intended so to do, would not render the trust enforceable. ${ }^{38}$ Clearly, however, if the devisee not only acknowledged the trust after learning of the testator's purpose, but

35 Gardner v. Rowe (1825) 2 Sim. \& Stu. 346, 3 I. J., Ch. 220, 25 Eng. Rep. R. 214; Bryant v. Klatt (1924) 2 Fed. (2d) 167.

30 Schultz's Appeal (1876) 80 Penn. St. 396.

37 O'Donnel v. Murphy (1911) 17 Cal. App. 625, 120 Pac. 1076; cf. Curdy v. Berton (1889) 79 Cal. 420, 21 Pac. 858, 12 Am. St. Rep. 157, 5 L. R. A. 189; Estate of Holt (1923) 61 Cal. App. 464, 215 Pac. 124; Gore v. Clark (1892) 37 S. C. 537, 16 S. E. 614. Also see Professor Costigan's able treatment of this subject in 28 Harvard Law Review, 366.

38 Flood v. Ryan (1908) 220 Penn. St. 450, 69 Atl, 908, 22 L. R. A. (N

S.) 1262 . 
received a consideration for so doing, the trust would be binding upon him.

In the case assumed above it is neither the statute of frauds nor the statute of wills that renders the trust unenforceable. Instead it is the lack of an acceptance (which as we have seen, by the nature of term, implies a consideration) or of a consideration in any form. But though there could be no acceptance in the proper sense of that term under the facts assumed, if the grantee subsequently acknowledged the trust and received a consideration therefor, the trust would thereby be rendered enforceable.

The conclusion would therefore seem to be sound that section 2222 of the Civil Code is perfectly reconcilable with the general law upon the subject, although originally based on a misleading dictum.

Ro'bert L. McWilliams.

Hastings College of the Law. 